\title{
Being Mindful of What is Absent
}

\author{
Bhikkhu Anālayo ${ }^{1}$
}

Accepted: 31 May 2021 / Published online: 7 October 2021

(c) The Author(s) 2021

\begin{abstract}
The cultivation of mindfulness in early Buddhist soteriology can comprise awareness of an absence. Such absence can be specific, in the sense of the absence of a particular mental condition. It can also take on a general sense, in that certain meditation practices that involve mindfulness can take as their object the notion that there is nothing at all. Besides being the standard approach for cultivating one of the immaterial spheres, a pre-Buddhist form of practice, the same notion that there is nothing can also be related to insight. Such insight could be retrospectively applied to the attainment of the immaterial sphere of nothingness, or else insight could be cultivated in conjunction with tranquility in a way that involves the same notion of nothingness, testifying to the interrelatedness of these two modalities of meditation in early Buddhism. In addition, the term nothingness can also serve as an epithet for the final goal of Nirvana, a usage that can also be related to mindfulness.
\end{abstract}

Keywords Absence $\cdot \bar{a} k i \tilde{n} c a \cdot$ amanasikāra $\cdot$ arūpa $\cdot$ Immaterial spheres $\cdot$ Insight $\cdot$ Non-attention $\cdot$ Non-mindfulness . Nothingness $\cdot$ satipațthāna $\cdot$ Tranquility $\cdot$ Upasīva

The cultivation of mindfulness can take place with a wide range of different objects, by way of remaining receptively aware and open to whatever happens to occur in the present moment. At times, however, mindfulness can also be called for to exercise a role of inhibiting an unreserved openness to what is happening, in particular when that involves something of an unwholesome nature.

\section{Non-Mindfulness}

The need to curtail at least to some extent the open receptivity of mindfulness appears to stand behind the idea of intentionally being "not-mindful" (asati/asmrti/不念/dran $m e d$ ). The relevant expression features in contexts where the recommendation is not to pay attention to a particular matter or mental condition. An example occurs in a series of recommendations on how to deal with recurrent unwholesome thoughts. One such method, which falls into place when another two methods have been tried and not been successful, takes the following form:

\section{Bhikkhu Anālayo}

1 Barre Center for Buddhist Studies, 149 Lockwood Road, Barre, Massachusetts 01005, USA
One should practice not attending to and not paying attention to these thoughts.

(MN 20: tesam vitakkānam asati amanasikāro apajjitabbo).

One should not attend to these thoughts.

(MĀ 101: 彼不念此念).

The translation "not attending to" or "not attend to" is guided by the context, in order to make sense of the instruction. A literal translation would be that one should cultivate being "not-mindful" in regard to such unwholesome thoughts. The idea here would be that, since a particular unwholesome thought pattern is so strong that previous attempts to settle the mind have been unsuccessful, the practitioner makes a conscious effort to ignore those thoughts. Notably, such intentional ignoring would still be a practice involving mindfulness in its general role of monitoring what is taking place. The function of mindfulness here would be to alert the practitioner to the rearising of this particular thought and then supervise the mind's intentional effort to forget about it.

A comparable instruction occurs in another context, where the task is to overcome resentment in regard to a particular person. In order to achieve that, one should make a similar effort to forget about this person (AN 5.161: asati amanasikāro ... a apajjitabbo), presumably in the sense of no longer paying attention to that person's particular quality or behavior which 
tends to trigger one's resentment. As in the case of recurrent unwholesome thoughts, resentment can captivate the mind and lead to endless inner tirades against the person experienced as irritating. Hence, the same mindful strategy of setting things aside, of intentionally forgetting and ignoring, can be helpful to escape from the vortex of such an obsessive mental condition.

The two passages surveyed above provide to some extent precedents to a concern with 'non-mentation' (amanasikāra) in later Buddhist traditions. Other precedents, already noted by Higgins (2006/2008, p. 255 n. 2) and Mathes (2009, p. 4), are the standard description of the meditative entry into the sphere of boundless space, which requires non-attention to perceptions of variety (MN 137: nānattasañãnanam amanasikārā and its parallel MĀ 163: 不念若干想; Anālayo 2020), and the meditative progression described in the Cūlasuññata-sutta and its parallels, to be examined below.

\section{Absence of Mental States}

Having successfully emerged from an obsessive unwholesome mental condition can in turn lead over to being mindful of its absence. Such mindfulness of a specific type of absence finds explicit inclusion in the instructions on contemplation of mental states, the third establishment of mindfulness (satipațthāna, smrtyupasthāna, 念處, dran pa nye bar gzhag pa). The relevant instructions mention not only mindful recognition of the presence of the root defilements but also of their absence. This can best be illustrated by extracting the parts relevant to the theme of absence from the instructions in the Satipatțhana-sutta and its two parallels:

One knows a mind without lust to be 'a mind without lust' ... [one knows a mind without anger to be 'a mind] without anger' ... [one knows a mind without delusion to be 'a mind] without delusion.'

(MN 10: vītarāgam vā cittam: vìtarāgam cittan ti pajānāti ... vītadosam ... vītamoham).

The mind being without sensual desire, one knows, as it really is, that the mind is without sensual desire ... [the mind being without anger, one knows, as it really is, that the mind is] without anger ... [the mind being without delusion, one knows, as it really is, that the mind is] without delusion.

(MĀ 98: 無欲心, 知無欲心如真 ... 無壳 ... 無癡).

The mind being without sensual craving, one also knows of oneself that the mind is without sensual craving ... the mind being without anger, one also knows of oneself that the mind is without anger ... the mind being without delusion, one in turn knows of oneself that the mind is without delusion.

$(E \bar{A}$ 12.1: 無愛欲心, 亦自覺知無愛欲心; ... 無槇 恚心, 亦自覺知無瞋壳心 ... 無愚癡心, 便自覺知 無愚癡心).

In this way, a specific type of absence can become an object of mindfulness practice. Such instruction is probably best understood within its context. Of particular relevance here is the preceding mention of having recognized with mindfulness that sensual desire, anger, or delusion was present. Such earlier recognition presumably forms the basis for then noticing whenever these detrimental qualities have gone into abeyance. Understood in this way, it is based on having familiarized oneself with the repercussions these three root defilements have on the condition of the mind that it becomes possible to notice when these repercussions no longer manifest. At such a time, the task of mindfulness is to be aware of an absence.

The same basic pattern applies to contemplation of the hindrances and of the awakening factors in the Satipatthāna-sutta and its Madhyama-ägama parallel (and to some extent even to a contemplation of the fetters arising at a sense door), where the meditator's task comprises being aware of the absence of the respective mental qualities. Here are the relevant passages for the first hindrance and the first awakening factor respectively:

If sensual desire is not present within, one knows: 'sensual desire is not present within me.'

(MN 10: asantam vā ajjhattam kāmacchandam: $n$ ' atthi me ajjhattam kāmacchando ti pajānāti).

There actually being no sensual desire within, one knows, as it really is, that there is no sensual desire. (MĀ 98: 內實無欲, 知無欲如真).

If the mindfulness awakening factor is not present within, one knows: 'the mindfulness awakening factor is not present within me.'

(MN 10: asantam vā ajjhattam satisambojjhangam: n'atthi me ajjhattam satisambojjhañgo ti pajānāti).

There actually being no mindfulness awakening factor within, one knows, as it really is, that there is no mindfulness awakening factor.

(MĀ 98: 內實無念覺支, 知無念覺支如真).

The last is particularly intriguing, as here it becomes a task of cultivating an establishment of mindfulness to notice when mindfulness, in its role as an awakening factor, is 
absent. This could be understood to refer to those moments when one suddenly realizes to have completely lost mindfulness for quite some time. In terms of recollecting oneself, this recognition is already an instance of mindfulness. Nevertheless, due to having just arisen after a period of being lost in distraction, such mindfulness is probably not yet strong enough to serve as an awakening factor.

The examples surveyed above show how specific types of absence can become objects of the cultivation of the establishments of mindfulness. Understood in this way, what is absent becomes present through its absence. The task of mindfulness is then precisely to be aware of the "presence" of such absence.

\section{The Sphere of Nothingness}

The notion of being mindful of an absence can be taken further. In the above examples, the absence was a specific one, namely of a particular mental state. However, absence can also take on a broader and more general scope, in the sense of there not being anything, leading to the notion of "nothing" (=not anything). Such total absence comes to the fore with the third of four deep tranquility attainments known as the immaterial spheres: the sphere of nothingness. Since mindfulness in its early Buddhist usage plays an important role in the achievement of states of mental tranquility (Anālayo 2019), a meditative cultivation of the sphere of nothingness does require mindfulness and would hardly be possible without it. In other words, such successfully attending to total absence (in the sense that there is nothing at all) still requires that mindfulness itself is not absent.

The early discourses present the sphere of nothingness as a pre-Buddhist practice. According to the traditional account, the Buddha-to-be cultivated this attainment under the guidance of a teacher by the name of Ātāra Kālāma (MN 26 and MĀ 204). The relevant Pāli discourse and its Chinese Ágama parallel do not provide further details about the kind of philosophy that inspired the mode of practice taught by Ālāra Kālāma. Nevertheless, indications found in other discourses make it probable that such practice involved the notion of realizing a subtle type of self, corresponding to the type of perception that is experienced by those who have mastered this attainment (Anālayo 2021).

From an early Buddhist perspective, however, the sphere of nothingness, together with its cosmological counterpart in the form of rebirth in the corresponding celestial realm, are simply modalities of creating a reified sense of identity (MN 106, MĀ 75, and Up 4058; Anālayo 2011, p. 617). For this reason, the Buddha-to-be was reportedly dissatisfied with the attainment he had reached under the tutelage of Ālāra Kālāma:

Monastics, it occurred to me: 'This Dharma does not lead to disenchantment, nor to dispassion, nor to cessation, nor to appeasement, nor to penetrative knowledge, nor to full awakening, nor to Nirvana, but just to reappearance in [the realm of] the sphere of nothingness. Monastics, I was thus dissatisfied with this Dharma and, turning away, I left this Dharma.

(MN 26: tassa mayham, bhikkhave, etad ahosi: nāyam dhammo nibbidāya na virāgāya na nirodhāya na upasamāya na abhiñ̃̄āya na sambodhāya na nibbānāya samvattati, yāvad eva ākiñcaññāyatanūpapattiyā ti. so kho aham, bhikkhave, tam dhammam analankkaritvā tasmā dhammā nibbijja pakkamim).

I further had this thought: 'This Dharma does not lead to knowledge, does not lead to awakening, does not lead to Nirvana. I would now rather leave this Dharma and continue searching for the supreme peace of Nirvana that is free from disease [etc.].'

(MĀ 204: 我復作是念: 此法不趣智, 不趣覺, 不趣 涅槃. 我今寧可捨此法, 更求無病無上安隱涅槃).

A minor difference is that the Chinese Ágama version does not explicitly refer to the topic of rebirth in the corresponding realm. In the main, however, the parallels agree in depicting the Buddha's disenchantment with the attainment of the sphere of nothingness. Another Pāli discourse indicates that cultivating the attainment of nothingness can lead to a form of rebirth that endures for the exceedingly long time of 60,000 eons (AN 3.114). Yet, the Buddha's quest was for a thorough and radical transcendence of the human predicament of being subject to old age, disease, and death. Hence, a mere postponement of being again subject to these, even though such adjournment would have lasted for an incredibly long time period, left him dissatisfied.

\section{Insight Perspectives on the Sphere of Nothingness}

Although the Buddha reportedly found that the attainment of nothingness did not lead him to the fulfillment of his quest for total freedom, its meditative cultivation is a recurrent topic in the early discourses. The attainment of the sphere of nothingness features as the last in listings of seven stations of consciousness (AN 7.41 and $E \bar{A}$ 39.5 ) and as the sixth in listings of eight liberations (AN 8.66). Together with rebirth in the corresponding realm, 
its attainment is reckoned to be supreme among modes of perception (AN 5.170 and SĀ 484). It constitutes a way of blindfolding Māra (MN 25 and MĀ 178), who stands representative of sensual temptation. The sphere of nothingness is a form of equanimity that is based on unity rather than on diversity (MN 137 and MĀ 163). Even though being a state of deep equanimity, it can be reckoned a form of happiness, and as such it is even subtler than the happiness of the immaterial spheres of infinite space or infinite consciousness (MN 59; SN 36.19; SHT II 51R, Waldschmidt et al. 1968, p. 10; and SĀ 485).

Alongside these positive evaluations, however, the early discourses also display a keen awareness of potential drawbacks of the attainment of the sphere of nothingness. For one, its experience can lead to misguided conceptual imaginations (MN 1; MĀ 106; T 56; EĀ 44.6). In fact, mastery of the attainment of the sphere of nothingness can become outright problematic if this becomes an occasion for the arousal of conceit:

By completely passing beyond the sphere of infinite consciousness, [aware that] 'there is nothing,' an unworthy person dwells having attained the sphere of nothingness. They think: 'I am a gainer of the attainment of the sphere of nothingness; these other monastics are instead not gainers of the attainment of the sphere of nothingness.' They praise themselves because of that attainment of the sphere of nothingness and disparage others. Monastics, this is also the nature of an unworthy person.

(MN 113: asappuriso sabbaso viñ̃ānanañāayatanam samatikkammā n' atthi kiñci ti ākiñcañ̃̃āyatanam upasampajja viharati. so iti pațisañcikkhati: aham kho 'mhi ākiñncaññāyatanasamāpattiyā lābh̄̄, ime

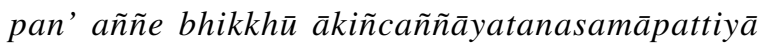
na lābhino ti. so tāya ākiñcaññāyatanasamāpattiya attānukkamseti, param vambheti. ayam pi, bhikkhave, asappurisadhammo).

Suppose one person attains the sphere of nothingness. Because of having attained the sphere of nothingness, they praise themselves and disparage others. This is reckoned to be the nature of an unworthy person.

$(M \bar{A}$ 85: 或有一人得無所有處, 彼因得無所有處故, 自貴, 賤他. 是謂不真人法; the original abbreviates and gives the full treatment only for the first absorption and the fourth immaterial sphere, from which text has been supplemented here. The corresponding presentation in another parallel, $\mathrm{T} 48$, seems to have suffered from a textual error; see Anālayo 2011, p. 643 n. 35. Yet another parallel, EA 17.9, just mentions accomplishment in concentration in general, without listing the different immaterial spheres).
Alongside some differences in wording, the above two parallels agree in depicting the arising of conceit based on having mastered the attainment of the sphere of nothingness. To avoid such a pitfall, the same attainment could become an object of insight meditation:

By completely passing beyond the sphere of infinite consciousness, [aware that] 'there is nothing,' one dwells having attained the sphere of nothingness. Whatever there actually is pertaining to feeling tone, pertaining to perception, pertaining to volitional formations, and pertaining to consciousness, one contemplates these states as impermanent, dukkha, a disease, a boil, a dart, a misery, an affliction, alien, disintegrating, empty, and not self.

(AN 9.36: sabbaso viñ̄̃ānañcāyatanam samatikkammā n' atthi kiñcī ti ākiñcañ̃̃ayatanam upasampajja viharati. so yad eva tattha hoti vedanāgatam sañ̃āgatam san்khāragatam viññannagatam, te dhamme aniccato dukkhato rogato gandato sallato aghato ābādhato parato palokato suñ̃nato anattato samanupassati).

By in this way turning the mind away from the attainment, the practitioner instead inclines it toward Nirvana. Such a reorientation in a way follows in the footsteps of the Buddha at the end of his period of apprenticeship under Ậāra Kālāma. The above discourse predicts that this mode of practice will lead to non-return or full awakening. Another mode of contemplation with the same potential takes the following form:

One understands: 'This attainment of the sphere of nothingness is also conditioned and produced by volition. Yet, whatever is conditioned and produced by volition, that is impermanent and of a nature to cease.'

(AN 11.17: ayam pi kho ākiñcaññāyatanasamāpatti abhisañkhatā abhisañcetayitā. yam kho pana kiñci abhisan்khatam abhisañcetayitam, tad aniccam nirodhadhamman ti pajānāti; see also Anālayo 2011, p. 311).

A shared feature in both types of instruction is directing attention to impermanence. The key here appears to be the realization that even such a profoundly tranquil and stable experience, not to speak of the incredibly long lifespan in the corresponding realm of existence, is subject to the law of change.

\section{A Convergence of Tranquility and Insight}

In addition to the possibility of cultivating insight (into impermanence and other perspectives) in relation to the deep level of tranquility gained with the sphere of nothingness, the early discourses also position the same attainment at a convergence point between tranquility and insight. The perspective afforded in this way is significant, as it shows that tranquility and insight are interrelated qualities in early 
Buddhism rather than being two incommensurable modes of meditation practice (Anālayo 2017, p. 173).

One modality for achieving such convergence can be seen in the Áneñjasappāya-sutta and its parallels, whose descriptions cover different meditative approaches to gaining the sphere of nothingness (Anālayo 2009). One of these approaches is based on insight into emptiness:

This is empty of a self and what belongs to a self. (MN 106: suñ̃nam idam attena vā attaniyena vā ti). This world is empty: empty of a self and what belongs to a self, empty of being permanent, empty of being everlasting, empty of existing continuously, and empty of being unchanging.

(MĀ 75: 此世空, 空於神, 神所有, 空有常, 空有恒, 空長存, 空不變).

The world is empty ... it is empty of permanence, of stability, of everlastingness, of immutable states, and it is devoid of a self and what belongs to a self.

(Up 4058: 'jig rten ni stong pa'o ... rtag pa dang, brtan pa dang, g.yung drung dang, mi 'gyur ba'i chos can gyis stong zhing bdag dang, bdag gi dang bral ba'o).

The Chinese and Tibetan parallels are more detailed, drawing out various additional perspectives on emptiness, beyond the absence of a self and what belongs to a self. Although in all versions the instruction is indubitably an insight contemplation, in the present setting its purpose is to lead to the attainment of the sphere of nothingness and thus to a tranquility attainment. This is thereby a case where insight meditation leads to tranquility.

The reverse of tranquility leading to insight into emptiness can be seen in the Cūlasuññata-sutta and its parallels (Anālayo 2015). The meditative trajectory described here appears to involve a gradual deconstruction of experience in order to lead to a realization of emptiness in its true and ultimate sense (as understood in early Buddhist thought), which requires emptying the mind of all defilements.

The meditative progression described in the Cülasuññata-sutta and its parallels for leading to this aim involves the perception of nothingness. The terminology used here differs from the standard description of how to gain the attainment of the sphere of nothingness, as it just speaks of the corresponding type of perception (ākiñcaññāyatanasaññam, 無所有處想, ci yang med pa' $i$ skye mched $d u$ 'du shes). This leaves open the possibility of cultivating this perception without having developed the full meditative mastery of the actual attainment (which in turn requires mastery of the four absorptions). Nevertheless, the perception itself clearly pertains to the realm of tranquility. In order to lead to the breakthrough to awakening, the entire series of perceptions cultivated in this meditative progression, of which the perception of nothingness is an integral part, needs to be contemplated in the following manner:

One understands that this is impermanent and of a nature to cease.

(MN 121: tad aniccaṃ nirodhadhamman ti pajānāti).

I do not delight in this, do not seek this; it is not suitable to be established in this.

(MĀ 190: 我不樂彼, 不求彼, 不應住彼).

It is not suitable to delight in it, to approve of it, to become attached to it, or to remain attached to it.

(Skilling 1994, 174: de la ni mngon par dga' bar bya ba 'am, mngon par brjod par bya ba 'am, lhag par chags par bya ba 'am, lhag par chags shing gnas par bya bar mi rigs so).

Whereas the Pāli version puts the spotlight on impermanence, the parallels depict the relinquishment of attachment that would naturally result from a full appreciation of impermanence. When viewed from this perspective, the parallels can be considered to provide somewhat complementary perspectives on the cultivation of liberating insight.

Just as the Aneñjasappāya-sutta and its parallels showcase the possibility of employing an insight perception to gain the attainment of the sphere of nothingness, similarly the Cūlasuññata-sutta and its parallels depict the option of relying on the perception of the sphere of nothingness to gain liberating insight. Since all of these modes of meditative cultivation involve mindfulness in one way or another, in these discourses the absence of anything as an object of mindfulness comes to be situated at a converging point of insight and tranquility.

\section{Nothingness as an Epithet of Nirvana}

The same notion of an absence of anything can also function as an epithet of the final goal of the early Buddhist path of practice. The rationale behind such usage can be deduced from the following passage, notably a teaching given by an accomplished lay meditator to a monastic audience:

Venerable sirs, lust is a something, anger is a something, delusion is a something. A monastic who has eradicated the influxes has abandoned these, cut them off at the root, made them like a palm stump, made to perish, of a nature not to arise again in the future. Venerable sirs, as far as there are liberations of the mind by nothingness, the unshakeable liberation of the mind is declared to be foremost among them. Moreover, that 
unshakeable liberation of the mind is empty of lust, empty of anger, and empty of delusion.

(SN 41.7: rāgo kho, bhante, kiñcanam, doso kiñcanam, moho kiñcanam. te khịnāsavassa bhikkhuno pahīnā ucchinnamūlā tālāvatthukatā anabhāvakatā āyatim anuppādadhammāa yāvatā kho, bhante, ākiñcañ̃̄a cetovimuttiyo, akuppā tāsam cetovimutti aggam akkhāyati. sā kho pana akuppā cetovimutti suñ̃̄a rāgena, suñ̃̃a dosena, suñ̃̄à mohena).

A lustful one is one who has a something; an angry one and a deluded one is one who has a something. An arahant is one who has nothing. Again, an arahant is empty; being empty of lust and empty of anger and delusion. (SĀ 567: 貪者是所有, 壳, 癡者是所有. 無猙者 是無所有. 復次, 無猙者空; 於貪空, 於恚, 癡空).

The notion that an arahant is empty in the sense of being free from the three roots of unwholesomeness recurs in a verse in the Dhammapada and its parallels. The relevant line reads as follows:

Afflictions do not befall one who has nothing.

(Dhp 221: akiñcanam nānupatanti dukkhā)

(Gāndhārī Dharmapada 274, Brough 1962/2001, p.

163: akijaṇa nanuvadadi dukhu).

(Patna Dharmapada 238, Cone 1989, p. 165:

akimcanam nānupatanti dukkhā).

The preceding lines make it clear that the reference is to an arahant, who has transcended the fetters and is not attached (to name-and-form). The reference to having nothing in the present line of the verse can be taken to carry the same implications as evident from the preceding passage, in that it is the very absence of defilements that makes up such nothingness.

Another verse, found in the Udāna, eulogizes the happiness that comes with such type of nothingness:

Happy indeed are those who have nothing, for sagely people have nothing. Behold [how] afflicted are those who have a something!

(Ud 2.6: sukhino vata ye akiñcanā, vedaguno hi janā akiñcanā; sakiñcanam passa vihañ̃amānam; a closely similar verse is extant in Sanskrit, Udānavarga 30.40: sukhino hi janā hy akiñcanā, vedaguṇā hi janā hy akiñcanāh, sakiñcanam paśya vihanyamānam).

Several verses in the Suttanipāta collection reflect a similar employment of the notion of nothingness. Two relevant instances concern being worthy of receiving offerings and thus a source of merit:
[One should make an offering to] those who fare in the world without attachment, having nothing.

(Sn 490: ye ve asattā vicaranti loke, akiñcanā).

[One should make an offering to] those who fare in the world as islands to themselves, having nothing, being freed in every respect.

(Sn 501: ye attadīpā vicaranti loke, akiñcanā sabbadhi vippamuttā).

A similar usage occurs in a verse that eulogizes the Buddha, spoken after he had given profound answers to several penetrative questions:

Behold the one of deep wisdom, who sees the subtle meaning, who has nothing, is not attached to sensuality and existence, and is freed in every respect.

(Sn 176: gambhīrapañ̃am nipuṇatthadassiṃ, akiñcanam kāmabhave asattam, tam passatha sabbadhi vippamuttam).

Another such verse occurs in the Pārāyana-vagga, the last chapter of the Suttanipāta collection.

One who has nothing, and is not attached to sensuality and existence, has certainly crossed this flood.

(Sn 1059: akiñcanam kāmabhave asattam, addhā hi so ogham imam atāri).

The other qualifications make it clear that here, once again, the notion of nothingness functions as an epithet of having reached the final goal.

\section{Being Mindful That There is Nothing}

Another verse in the same Pāräyana-vagga, spoken by the Buddha in reply to a question asked by the young brahmin Upasiva, explicitly brings in mindfulness:

Being endowed with mindfulness and observing nothingness, in dependence on 'there being nothing' you will cross over the flood.

(Sn 1070: ākiñ̃añ̃nam pekkhamāno satimā, n'atthī ti nissāya tarassu oghaṃ).

Early and later Theravāda commentaries consider this line to intend the attainment of the sphere of nothingness, offering the following gloss of the supposed import of the instruction:

Having mindfully attained the attainment of the sphere of nothingness and having emerged from it, observing the states of mind and mental factors arisen therein as impermanent, as unsatisfactory ...

(Nidd II 101: ākiñncañ̃āayatanasamāpattim [sato samāpajjitvā tato vutțhahitvā] tattha jāte citta-cetasike dhamme aniccato pekkhamāno dukkhato ...). 
Having mindfully attained and emerged from the attainment of the sphere of nothingness, looking at it by way of impermanence and so on.

(Pj II 593: ākiñcañ̃āayatanasamāpattim sato samāpajjitvā vuțthahitvā ca aniccādivasena passamāno).

Yet, if the import of the Buddha's instruction had been to encourage contemplation of impermanence (and related insight perspectives), it would be difficult to understand why these are not explicitly taken up in the verse. The actual formulation of the instruction instead presents mindfulness of nothingness itself as the main means for crossing the flood. Nothingness is in fact mentioned twice: "observing nothingness, in dependence on 'there being nothing" (ākiñcañ̃nam pekkhamāno ... n' atthī ti nissāya). Forgoing such repetition would have left ample space to offer at least a short pointer at impermanence, had this been the intention. In other words, the verse in question does not provide support for assuming that its purpose is to commend contemplation of transience.

After the line translated above, the stanza continues with more general recommendations, namely the need to abandon sensuality, to avoid (excessive) talking, and to be devoted continuously to reaching the destruction of craving. As far as the actual meditation instructions are concerned, however, these are found in the verse translated above and revolve around the notion of nothingness, without offering even a passing reference to other insight perspectives.

In a detailed study of the exchange between the Buddha and Upasīva, which in the context of the present exploration cannot be done full justice to, Wynne $(2007,90)$ suggested that Upasivva would "have believed that the Buddha, speaking about someone maintaining awareness of 'nothingness,' was talking about the meditative 'anticipation,' in life, of liberation that he believed - according to the standard view - was attained at death" by those who had mastered the attainment of the sphere of nothingness.

Such a perspective would indeed help make sense of the verse exchange between Upasiva and the Buddha as a whole. However, pace Wynne $(2007,106)$, this need not be taken to imply that "the Buddha teaches an adapted form of the meditative exercise of Ālāra Kālāma." Instead, it seems more convincing to assume that the Buddha's first reply involved an employment of the term "nothingness" in line with the other occurrences in the Suttanipāta, surveyed above. Perhaps an early version of the commentary on this exchange recognized that the ensuing verses show that Upasīva had misunderstood this reference to intend the attainment of the sphere of nothingness. In the course of transmission, the commentators may then have mistakenly extended this explanation also to the Buddha's initial statement. As a result, they had to bring in the topic of insight in some other way. In line with the passages surveyed above that depict insight into the impermanent (etc.) nature of such attainment (AN 9.36 and AN 11.17), it would have been natural for the idea to arise that the recommendation given to Upasivva must have been meant to encourage such insight contemplation, to be undertaken after having arisen from the actual attainment of the sphere of nothingness.

The impression that the recommendation to be mindful of nothingness in the verse translated above probably did not intend the attainment of the sphere of nothingness finds support on consulting the preceding question (Sn 1069). Upasīva had asked how to cross the flood and requested the Buddha to point out a support with the help of which this can be accomplished. It would be strange for the Buddha to be depicted as replying to such a clear-cut request for the path to liberation by recommending just the attainment of the sphere of nothingness. According to the account of his own quest for awakening, he knew that the sphere of nothingness does not lead beyond the flood. For this reason, it would be difficult to understand why he should present the same here as the support required for crossing over the flood.

The impression that the Buddha's reply is more convincingly read as intending Nirvana finds further support in another verse exchange in the Pārayyana-vagga. In this case, the Buddha was asked to point out an island amidst the fearful flood. The relevant part of the reply takes this form:

Having nothing, taking up nothing, this is the unsurpassable island. I call it Nirvana, the destruction of old age and death.

(Sn 1094: akiñcanam anādānam, etam

dīpam anāparaṃ; nibbānam iti nam brūmi, jarāmaccuparikkhayam).

In this case, the stanza itself clarifies that the reference to nothingness intends Nirvana. The same sense appears to be also appropriate to the exchange with Upasīva. On this understanding, the verse spoken to Upasīva presents the practice of mindfulness directed to an observation of the notion of nothingness as a key element in support of one possible modality for progressing to awakening.

Abbreviations AN: Anguttara-nikāya; Dhp: Dhammapada; EĀ: Ekottarika-āgama (T 125); MĀ: Madhyama-āgama (T 26); MN: Majjhima-nikāya; Nidd: Niddesa; Pj: Paramatthajotikā; SĀ: Samyukta-āgama (T 99); SHT: Sanskrithandschriften aus den Turfanfunden; SN: Samyutta-nikāya; Sn: Suttanipāta; T: Taishō edition; Ud: Udāna; Up: Abhidharmakośopāyikā-țīkā 
Funding Open Access funding enabled and organized by Projekt DEAL.

\section{Declarations}

Ethical Approval This article does not contain any studies performed by the author with human participants or animals.

Conflict of Interest The author declares that there is no conflict of interest.

Open Access This article is licensed under a Creative Commons Attribution 4.0 International License, which permits use, sharing, adaptation, distribution and reproduction in any medium or format, as long as you give appropriate credit to the original author(s) and the source, provide a link to the Creative Commons licence, and indicate if changes were made. The images or other third party material in this article are included in the article's Creative Commons licence, unless indicated otherwise in a credit line to the material. If material is not included in the article's Creative Commons licence and your intended use is not permitted by statutory regulation or exceeds the permitted use, you will need to obtain permission directly from the copyright holder. To view a copy of this licence, visit http://creativecommons.org/licenses/by/4.0/.

\section{References}

Anālayo, Bh. (2009). The Āneñjasappāya-sutta and its parallels on imperturbability and on the contribution of insight to the development of tranquillity. Buddhist Studies Review, 26(2), 177-195. https://doi.org/10.1558/bsrv.v26i2.177
Anālayo, Bh. (2011). A comparative study of the Majjhima-nikāya. Taipei: Dharma Drum Publishing Corporation.

Anālayo, Bh. (2015). Compassion and emptiness in early Buddhist meditation. Cambridge: Windhorse Publications.

Anālayo, Bh. (2017). Early Buddhist meditation studies. Barre: Barre Center for Buddhist Studies.

Anālayo, Bh. (2019). The role of mindfulness in the cultivation of absorption. Mindfulness, 10(11), 2341-2351. https://doi.org/10. 1007/s12671-019-01206-7

Anālayo, Bh. (2020). Attention and mindfulness. Mindfulness, 11(5), 1131-1138. https://doi.org/10.1007/s12671-019-01286-5

Anālayo, Bh. (2021). The Buddha's pre-awakening practices and their mindful transformation. Mindfulness 12(7), 1892-1898. https:// doi.org/10.1007/s12671-021-01646-0

Brough, J. (1962/2001). The Gāndhārī Dharmapada, edited with an introduction and commentary. Delhi: Motilal Banarsidass.

Cone, M. (1989). Patna Dharmapada. Journal of the Pali Text Society, $13,101-217$.

Higgins, D. (2006/2008). On the development of the non-mentation (amanasikāra) doctrine in Indo-Tibetan Buddhism. Journal of the International Association of Buddhist Studies, 29(20), 255-303.

Mathes, K.-D. (2009). Maitrīpa's amanasikārādhāra ('a justification of becoming mentally disengaged'). Journal of the Nepal Research Center, 13, 1-30.

Skilling, P. (1994). Mahāsūtras: Great discourses of the Buddha. Oxford: Pali Text Society.

Waldschmidt, E., Clawiter, W., \& Sander-Holzmann, L. (1968). Sanskrithandschriften aus den Turfanfunden, Teil II. Wiesbaden: Franz Steiner Verlag.

Wynne, A. (2007). The origin of Buddhist meditation. London: Routledge.

Publisher's Note Springer Nature remains neutral with regard to jurisdictional claims in published maps and institutional affiliations. 